with evidence of the self-inflicted nature of their lesions and, when suspected, usually reject offers of psychiatric assistance and discharge themselves. There is no easy way of helping them and there are normally insufficient grounds for compulsory admission to psychiatric hospitals. However, they can at least be protected from the results of their own behaviour by dissemination of information about them among doctors and hospitals.

\section{References}

AsHer, R. (1951) Münchausen's Syndrome. Lancet, i, 339. Mayer-Gross, W., Slater, Eliot \& Roth, M. (1969) Clinical Psychiatry (Ed. by Eliot Slater and M. Roth), p. 115. Baillière, Tindal and Cassell, London.

\title{
Water intoxication associated with oxytocin infusion
}

\author{
Audrey J. Ahmad \\ M.B., B.S., M.R.C.P. \\ Elizabeth H. Clark \\ M.B., B.S. \\ HOWARD S. JACOBS* \\ B.A., M.D., M.R.C.P.
}

Central Middlesex Hospital, London

\begin{abstract}
Summary
During a mid-trimester abortion with high dose oxytocin infusion and intravenous fluids, a patient developed an acute dilutational hyponatraemia and coma. The relationship of water intoxication and synthetic oxytocin infusion is discussed and the literature reviewed.
\end{abstract}

Although twenty-three cases of water intoxication complicating infusion of oxytocin, including two maternal deaths (Lilien, 1968; Gupta and Cohen, 1972), have been recorded in the Commonwealth and North American literature (Liggins, 1962; Pittman, 1963; Whalley and Pritchard, 1963; Potter, 1964; Self, 1966; Silva and Allan, 1966; King and Hall, 1966; Brennan, Madden and Massant, 1967; Leventhal and Reid, 1968; Burt, Oliver and Whitener, 1969; Josey, Pinto and Plant, 1969; Bileck and Dorr, 1970; Storch, 1971; Turcot, 1971; Goodlin, McLennon and Choyce, 1969; Pedlow, 1970), the association is still not widely recognized. Thus, no mention is made of it in several of the standard text books of obstetrics, despite the fact that infusion of oxytocin in high dosage was first recommended for the treatment of missed abortions 15 years ago (Loudon, 1959) and water intoxication was first attributed to this form of treatment in 1962 (Liggins, 1962). The case of severe water intoxication associated with an infusion of oxytocin reported here may serve as a reminder of the potential hazards of a widely

* Present address: Department of Obstetrics and Gynaecology, St Mary's Hospital Medical School, London W2 1 PG. used procedure, and of the precautions which must be observed.

\section{Case report}

A 24-year-old woman was admitted to a district hospital for a therapeutic abortion because of an attack of rubella in the tenth week of pregnancy. She was a healthy-looking, well nourished primigravida, 17 weeks pregnant, with no abnormality on physical examination, and with no relevant past or family history.

At midday on the day of admission an intra-uterine injection of $20 \%$ saline was given, and an intravenous infusion of oxytocin in $5 \%$ dextrose in water started. In the first $10 \mathrm{hr}$ she received $10 \mathrm{u}$ of oxytocin in 1 litre of fluid and, as she did not abort, the rate of administration was progressively increased (Table 1). While the fourth and fifth litres were being infused, she was seen to be restless, drowsy and confused, and she vomited twice. About $38 \mathrm{hr}$ after the infusion was started, she was found on the floor beside the bed, restless, comatose, and responding only to pain. The pupils were equal, widely dilated, and reacted sluggishly to light; the tendon reflexes were uniformly brisk and the plantars were flexor. There was no papilloedema. The pulse and blood pressure were normal. Seven hours later at 9.00 a.m. her condition remained unchanged. Blood was sent for urea and plasma electrolyte estimation. A plain X-ray of the skull did not show any fracture. Frusemide $(80 \mathrm{mg})$ was given intravenously and intravenous dexa- 
TABLE 1. Fluids and oxytocin infused in first $41 \mathrm{hr}$

\begin{tabular}{cccc}
\hline $\begin{array}{l}\text { Vol. of } \\
\text { dextrose (1) }\end{array}$ & $\begin{array}{l}\text { Units of } \\
\text { oxytocin }\end{array}$ & Time (hr) & $\begin{array}{c}\text { Rate of } \\
\text { oxytocin } \\
\text { infusion } \\
(\mathrm{mu} / \mathrm{min})\end{array}$ \\
\hline 1 & 10 & 10 & 17 \\
1 & 20 & 8 & 42 \\
1 & 40 & 12 & 56 \\
1 & 40 & 5 & 133 \\
1 & 40 & 6 & 111 \\
\hline
\end{tabular}

methasone started. At noon, still comatose, the patient aborted,with complete expulsion of the products of conception. In the preceding $48 \mathrm{hr}$ her total fluid intake had been at least 5.51 , including $500 \mathrm{ml}$ orally, and her output 2.51 of urine and about 1 litre of vomitus. She was then given $500 \mathrm{ml}$ of $10 \%$ mannitol intravenously, followed by more $5 \%$ dextrose. A brisk diuresis began, the exact quantity of which is uncertain.

As there was no improvement in her level of consciousness during the afternoon, she was transferred to the Neurological Unit at the Central Middlesex Hospital at 5.00 p.m., by which time she had received another $750 \mathrm{ml}$ of $5 \%$ dextrose solution. On arrival she was comatose, resentful of handling, responsive to pain only, and had pathologically brisk reflexes but flexor plantars. There was no oedema or visible venous engorgement. Her blood pressure had fallen from the reading of $120 / 70 \mathrm{mmHg}$ obtained in the referring hospital to $90 / 70 \mathrm{~mm} \mathrm{Hg}$, and her pulse rate had risen from 80 to $100 / \mathrm{min}$ but other clinical findings were essentially normal.

At this time the results of the 9 a.m. estimation of blood urea and plasma electrolytes became available. These results and those of urgently-repeated measurements showed a severe hyponatraemia, with a plasma sodium of only $100 \mathrm{mEq} / \mathrm{l}$ at $9 \mathrm{a} . \mathrm{m}$. and $114 \mathrm{mEq} / \mathrm{l}$ at 5 p.m. At the time of the second measurement of serum sodium the blood urea was $8 \mathrm{mg} / 100 \mathrm{ml}$, plasma potassium $2.8 \mathrm{mEq} / 1$, chloride $88 \mathrm{mEq} / \mathrm{l}$, and bicarbonate $12 \mathrm{mEq} / \mathrm{l}$, with a measured serum osmolality of $237 \mathrm{mOs} / \mathrm{kg}$. These results, which indicated a dilutional hyponatraemia, confirmed the clinical diagnosis of water intoxication. Accordingly the intravenous infusion was stopped and all fluids were withheld. No diuretics were given, but treatment with dexamethasone was continued for 4 days. The blood count at this time was normal apart from a slight neutrophilia, $\mathrm{Hb}$ was $12.7 \mathrm{~g} / 100 \mathrm{ml}$, and blood cultures subsequently proved negative.

After a few hours, during which her neurological state fluctuated between coma with dilated pupils and stupor with normally-reacting pupils, the patient began to improve steadily. For the first 3 days the volume of her urine output remained low (average $550 \mathrm{ml} / 24 \mathrm{hr}$ ) in spite of a low serum osmolality, and for a week there was no detectable sodium in her urine at all. Her serum potassium, however, returned to normal, without supplement, within $24 \mathrm{hr}$. She first began to speak $48 \mathrm{hr}$ after transfer, by which time her measured serum osmolality had risen to $261 \mathrm{mOs} / \mathrm{kg}$. Oral fluids were restarted only when she began to feel thirsty, which occurred 3.5 days after fluids were withheld, by which time her serum osmolality had risen to $293 \mathrm{mOs} / \mathrm{kg}$. She was discharged from hospital 5 days later completely recovered, mentally normal apart from amnesia for the period of coma and stupor and with normallyreacting pupils and normal reflexes. At the time of discharge the serum creatinine was $0.6 \mathrm{mg} / 100 \mathrm{ml}$ and creatinine clearance $66 \cdot 2 \mathrm{ml} / \mathrm{min}$. An IVP a few days later was normal.

\section{Discussion}

Water intoxication associated with oxytocin infusion was first reported by Liggins in 1962. This case and ten others subsequently reported were reviewed by Abdul-Karim and Rizk in 1970, together with the results of a number of studies on the effect of oxytocin on renal haemodynamics and water and electrolytes in animals and humans. The conclusion of these authors was that, in healthy women, oxytocin administered by constant intravenous infusion produced a definite anti-diuresis from within 10 to $15 \mathrm{~min}$ of the start of the infusion until 10-15 min after it was stopped. This anti-diuresis was found to be dosedependent, being readily detectable at $15 \mathrm{mU} / \mathrm{min}$ and maximum $45 \mathrm{mU} / \mathrm{min}$ ( $20 \mathrm{U}$ oxytocin in 1 litre fluid at $40 \mathrm{drops} / \mathrm{min}$ ). Of great importance was the observation that $70 \%$ of the total anti-diuretic effect occurred at infusion rates of $20-30 \mathrm{mU} / \mathrm{min}$. Oxytocin caused a marked decrease in free water clearance, which in some subjects became negative.

Previously reported cases of water intoxication have been associated with doses of oxytocin ranging from 60 to $820 \mathrm{U}$, and with rates of infusion varying from 43 to $1366 \mathrm{mU} / \mathrm{min}$, with large amounts (mostly from 4 to $9 \mathrm{l}$ ) of electrolyte-free solutions administered in from 7 to $43 \mathrm{hr}$. Our patient had received $150 \mathrm{U}$ of oxytocin in 51 of electrolyte-free solution in about $41 \mathrm{hr}$, at a rate which varied from 17 to 133 $\mathrm{mU} / \mathrm{min}$, and averaged $61 \mathrm{mU} / \mathrm{min}$. Her serum sodium reached the remarkably low level of 100 $\mathrm{mEq} / \mathrm{l}$, the lowest in any of these cases.

Turcot (1971) has described three conditions for the development of water intoxication: large doses of oxytocin; a large volume of hypotonic solution; infusion over a short period of time. Whereas the doses of oxytocin used for induction of labour at term are usually below $10 \mathrm{mU} / \mathrm{min}$ and rarely exceed $20 \mathrm{mU} / \mathrm{min}$, infusion rates considerably in excess of the latter figure are commonly required to empty the 
uterus in the second trimester of pregnancy. The high rate of infusion required by our patient reflects this relative uterine insensitivity to oxytocin, and suggests that for abortion during this stage of pregnancy alternative means (for instance, by prostaglandin infusion) may be preferable.

Opinion is divided on the role of saline in preventing and treating oxytocin-associated water intoxication. Abdul-Karim and Rizk (1970) recommended giving oxytocin in isotonic saline to reduce the hazard of hyponatraemia, but this was thought by Bilek and Dorr (1970) to increase the risk of pulmonary oedema and toxaemic eclampsia. Presumably the mechanism for the development of water intoxication is the combination of a block to free water clearance by the anti-diuretic activity of the infused oxytocin, and the infusion of large amounts of electrolyte-free fluid. Restriction of the volume of fluid of any type given during the oxytocin infusion should, therefore, help to prevent the development of hyponatraemia. Particular care is necessary in patients with impaired renal function or in those already receiving medication likely to influence renal water and electrolyte excretion. Note should particularly be taken of associated analgesic therapy, since pethidine and morphia may seriously impair urine formation in the hydrated subject (Liggins, 1963), presumably by stimulating endogenous vasopressin secretion at a time when it would normally be markedly inhibited by the water load.

Treatment of oxytocin-associated water intoxication has usually been by infusion of hypertonic saline. Turcot (1971) advocated stopping oxytocin and giving intravenous hypertonic saline if hyponatraemia were severe, or mannitol if it were not. In the case reported here, mannitol had already been given for cerebral decompression before the diagnosis of water intoxication was made. Hypertonic saline was not given on the grounds that firstly, since the anti-diuretic effect of oxytocin should have ceased within about $15 \mathrm{~min}$ of stopping it, the water load itself should act as an effective diuretic with less risk of pulmonary oedema; secondly, the patient had already received a large amount of hypertonic saline by intra-uterine injection.

In reviewing the reason for this patient's relatively slow diuresis after all fluids were withheld, the two main possibilities considered were (a) that fluid retention had caused swelling of the renal parenchyma and (b) that the patient had become sodium-depleted as a result of vomiting. It was noted that, even when her serum osmolality had risen to $293 \mathrm{mOs} / \mathrm{kg}$, there was no detectable sodium in her urine. However, since her blood chemistry was able to return to normal, with complete clinical recovery and the restoration of normal blood pressure, without the administration of any sodium supplement at all, it was thought that any serious degree of sodium depletion was unlikely.

Intravenous therapy with oxytocin is so widely and safely used that the risks may sometimes be overlooked. Since the dangers are dose related, particular care is required when oxytocin is used to induce midtrimester abortion. It is of interest that, in previously reported cases as in this one, most patients developing hyponatraemia complained of nausea and vomiting as an early symptom. This symptom is common in patients being aborted with the aid of infused oxytocin (Craft and Musa, 1971): although no measurements are available, it is possible that some of the patients complaining of nausea and vomiting are developing mild degrees of water intoxication. Oliguria is another danger sign: it could indicate either incipient water intoxication if too much fluid is being given, or dehydration if fluid restriction has been too severe; in any event it is an indication for interrupting the oxytocin infusion until serum electrolytes have been estimated and diuresis re-established. Careful monitoring of the oxytocin dosage and rate of infusion, the nature and amount of fluids given, and the urinary output are clearly mandatory if iatrogenic water intoxication is to be avoided.

\section{Acknowledgments}

We would like to thank Dr L. S. Lange for permission to report details of this case. We are particularly grateful to Mr M. D. G. Gillmer and Mr D. B. Paintin for helpful advice during preparation of the manuscript.

\section{References}

Abdul-Karim, R.W. \& Rizk, P.T. (1970) The effect of oxytocin on renal hemodynamics, water and electrolyte excretion. Obstetrical and Gynecological Survey, 25, 805.

BILEK, W \& DorR, P. (1970) Water intoxication and Grand Mal seizures due to oxytocin. Canadian Medical Association Journal, 103, 379.

Brennan, J.J., Madden, R.F. \& Massant, J.J. (1967) Water intoxication associated with oxytocin. Wisconsin Medical Journal, 66, 133

Burt, R.L., Oliver, K.L. \& Whitener, D.L. (1969) Water intoxication complicating elective induction of labour at term. Report of a patient who survived. Obstetrics and Gynecology, 34, 212.

CrafT, I. \& MUSA, B. (1971) Induction of mid-trimester therapeutic abortion by intra-amniotic urea and intravenous urea. Lancet, ii, 1058.

Goodlin, R.C., McLennan, C.E. \& Choyce, J.M. (1969) Therapeutic abortion with hypertonic intra-amniotic saline. A clinical experience in a combined community university hospital. Obstetrics and Gynecology, 34, 1.

GUPTA, D.R. \& COHEN, N.H. (1972) Water intoxication due to high doses of synthetic oxytocin. Journal of the American Medical Association, 220, 681.

Josey, W.E., Pinto, A.P. \& Plant, R.F. (1969) Oxytocin induced water intoxication. American Journal of Obstetrics and Gynecology, 104, 926.

KING, T.M. \& HALL, D.G. (1966) Water intoxication in obstetrics. Missouri Medicine, 63, 359.

LeVenthal, J.M. \& ReID, D.E. (1968) Oxytocin induced water intoxication with Grand Mal convulsion. American Journal of Obstetrics and Gynecology, 102, 310. 
Liggins, G.C. (1962) Acute water retention associated with continuous slow infusion of oxytocin. Journal of Obstetrics and Gynaecology of the British Commonwealth, 69, 277.

Liggins G.C. (1963) Antidiuretic effects of oxytocin, morphia and pethidine in pregnancy and labour. Australian and New Zealand Journal of Obstetrics and Gynaecology, 3, 81.

LILIEN, A.A. (1968) Oxytocin induced water intoxication; report of a maternal death. Obstetrics and Gynecology, 32, 171.

LouDon, J.D.O. (1959) The treatment of missed abortion by high dosage syntocinon intravenous infusion. Journal of Obstetrics and Gynaecology of the British Commonwealth, 66, 277.

Pedlow, P.R.B. (1970) Water intoxication induced with oxytocin. Journal of Obstetrics and Gynaecology of the British Commonwealth, 77, 1113.
Pitrman, J.G. (1963) Water intoxication due to oxytocin. New England Journal of Medicine, 268, 481.

PotTer, R.R. (1964) Water intoxication due to oxytocin. Obstetrics and Gynecology, 23, 699.

SELF, J. (1966) Water intoxication induced by oxytocin administration. American Journal of the Medical Sciences. 252, 573.

Silva, P. \& Allan, M.S. (1966) Water intoxication due to high doses of synthetic oxytocin. Obstetrics and Gyneco$\log y, 27,517$.

StorCH, A.S. (1971) Acute water retention associated with continuous slow infusion of oxytocin. Obstetrics and Gynecology, 37, 109.

TuRCoT, M.J.P. (1971) Water intoxication induced with oxytocin. L'Union Médicale du Canada, 100, 1997.

Whalley, P.J. \& PRitchard, J.A. (1963) Oxytocin and water intoxication. Journal of the American Medical Association. 186, 601 .

\title{
Malignant gonadal tumour formation in intersexual states
}

\author{
H. W. S. PigotT \\ M.B., F.R.C.S.
}

The Surgical Unit, Westminster Hospital, London

\begin{abstract}
Summary
Two cases of malignant tumour are reported in phenotypically male hermaphrodites. The importance of establishing the presence of persistent Müllerian duct structures in pseudo-hermaphrodites is discussed in relation to prophylactic castration in anticipation of malignant change.
\end{abstract}

\section{Introduction}

This paper describes two cases of tumour formation in the gonads of hermaphrodites, which is a rare complication of an uncommon condition. The first patient went unrecognized as an intersexual state for many years. The second case is of a malignant ovarian tumour with normal fallopian tube in the scrotum of an outwardly normal male, and may be unique.

\section{Case 1}

M.M. was born with a moderately severe hypospadias and an absent right testicle. He was raised as a boy, and when 5 years old he started a series of staged urethroplasty operations. In addition, a short course of male hormone was given in an attempt to produce testicular descent on the right side. At the

Correspondence: Mr H. W. S. Pigott, Lecturer in Surgery, The Surgical Unit, Westminster Hospital, London S.W.1. age of 14 a mammoplasty was performed for rightsided gynaecomastia. At the age of 16 his mother reported a brief episode of haematuria, and at this time his sexual status was questioned.

In view of the patient's physique, hair distribution and ability to achieve erection, he was judged to be a male. At the age of 21 the patient received psychiatric help for an anxiety neurosis, which continued for the rest of his life. At the age of 27 he attended the surgical outpatients' department complaining of a painful swelling in the left testicle. Physical examination revealed an absent right testicle; the left testicle was replaced by a slightly tender indurated mass $8 \mathrm{~cm}$ in diameter. The penis was small and was scarred by previous urethroplasty. In addition, the patient was short and spoke with a high pitched voice. Exploration of the scrotum showed a haemorrhagic tumour and an orchidectomy was performed. There was no clinical evidence of distant metastases, and lymphangiography showed no abnormality of the abdominal nodes. Histological examination showed a malignant teratoma (see Fig. 1).

Postoperatively a course of radiotherapy was given to the penis and para-aortic glands (4300 rad). Six months later a scrotal recurrence was treated by an iridium implant (4600 rad) with regression. Fifteen months following the original operation, pulmonary 